\title{
Effects of Theobromine and Caffeine on Muscle Fatigue Levels after Maximum Physical Activity (Experiment on Male Wistar Rats)
}

\author{
Taufiq Hidayah $^{1, *}$, Andry Akhiruyanto ${ }^{1}$, Sugiarto ${ }^{1}$, Dewangga Yudhistira ${ }^{1}$, Sulistiyono ${ }^{2}$, \\ Aan Wahyu Setiawan' \\ ${ }^{1}$ Fakultas Ilmu Keolahragaan, Universitas Negeri Semarang, Indonesia \\ ${ }^{2}$ Fakultas Ilmu Keolahragaan, Universitas Negeri Yogyakarta, Indonesia
}

Received October 26, 2021; Revised December 27, 2021; Accepted January 16, 2022

\section{Cite This Paper in the following Citation Styles}

(a): [1] Taufiq Hidayah, Andry Akhiruyanto, Sugiarto, Dewangga Yudhistira, Sulistiyono, Aan Wahyu Setiawan, "Effects of Theobromine and Caffeine on Muscle Fatigue Levels after Maximum Physical Activity (Experiment on Male Wistar Rats)," International Journal of Human Movement and Sports Sciences, Vol. 10, No. 1, pp. 45 - 48, 2022. DOI: 10.13189/saj.2022.100107.

(b): Taufiq Hidayah, Andry Akhiruyanto, Sugiarto, Dewangga Yudhistira, Sulistiyono, Aan Wahyu Setiawan (2022). Effects of Theobromine and Caffeine on Muscle Fatigue Levels after Maximum Physical Activity (Experiment on Male Wistar Rats). International Journal of Human Movement and Sports Sciences, 10(1), 45 - 48. DOI: 10.13189/saj.2022.100107.

Copyright $\mathrm{C} 2022$ by authors, all rights reserved. Authors agree that this article remains permanently open access under the terms of the Creative Commons Attribution License 4.0 International License

\begin{abstract}
Muscle fatigue often occurs when a person performs a maximal activity. However, some substances are believed to be able to improve exercise performance and control energy due to muscle fatigue called ergogenic substances. Ergogenic substances that are not included in the doping category are theobromine and caffeine. Unfortunately, there are very few exercise studies examining theobromine and caffeine, so further testing to prove their benefits is still needed. Therefore, this study aims to determine the effect of the administration of ergogenic theobromine and caffeine after the maximum activity so that a decrease in lactic acid levels can be found. This research is an experimental study with laboratory testing and is carried out based on a random control posttest approach. Sampling was done by using the total sampling technique. The research sample was 18 male Wistar rats aged 2-3 months with a weight of 150-250 grams. Samples were divided into 3 groups consisting of the control group, theobromine group, and the caffeine group. The instrument for taking blood samples is accutrend plus. The data obtained were analyzed using descriptive analysis. The hypothesis was tested using One Way Anova with the help of SPSS 16. The tests carried out found that the average values of the control group, theobromine, and caffeine were 5.2, 4.9,
\end{abstract}

and 4.2 , respectively. The results of the hypothesis test showed that the significance value obtained was $0.35>$ 0.05 which indicated that the hypothesis was rejected. In conclusion, the administration of ergogenic theobromine and caffeine did not give a significant difference in reducing lactic acid levels. This invention can thus be used as a reference for athletes not to use these substances to reduce fatigue and increase energy.

Keywords Theobromine, Caffeine, Muscle Fatigue, Lactic Acid, Physical Activity

\section{Introduction}

Physical activity is described as the movement of the body so that energy is produced. Conceptually, physical activity can be done with low to maximum intensity [1]. Physical activity provided programmatically can have a positive impact on the body, such as increasing physical and psychological fitness [2][3][4] system provides energy for short, maximal-intensity physical activity. However, if physical activity continues, the energy system used is anaerobic glycolysis which is obtained from muscle 
glycogen and blood glucose. This system produces 2-3 ATP from carbohydrates with a byproduct of lactic acid [5][6].

Muscle contractions that work repeatedly for a long duration trigger fatigue [7]. Fatigue is the inability of muscles to maintain and maintain strength to produce energy expenditure. Fatigue in this case is associated with decreased glycogen reserves caused by the intensity and duration of physical activity [8][9][10][6]. Fatigue occurs because of the role of lactic acid and can be defined as a decrease in muscle strength and power, causing disturbances during training and competition [11]. Many athletes, therefore, consume ergogenic substances or substances to increase productivity and control energy [9] One of the ergogenic substances that can be used is caffeine and theobromine [12].

Several past studies have reported that caffeine consumption before physical activity will help produce ergogenic effects and improve performance in sports $[13][14][15][16]$. Research on the effect of giving theophylline and theobromine on physical activity recently revealed that theobromine has a caffeine-like effect. Theophylline and theobromine have therefore become agents used in enhancing sports performance. Only one study was found regarding theobromine administration based on investigations in several works of literature. This leads the author to argue that studies on giving theobromine to physical activity are still very limited [12]

Based on the description above, it has been explained that fatigue is the inability of muscles to perform physical activity. Therefore, substances are needed to reduce lactic acid levels. Therefore, this study aims to determine the effect of caffeine and theobromine on the level of muscle fatigue after maximal activity. This study hypothesized that caffeine and theobromine had a significant effect on reducing lactic acid levels in muscles after maximal physical activity.

\section{Materials and Methods}

The type of this research is experimental research with laboratory testing. Laboratory testing is a scientific testing activity that is applied as a theoretical and practical approach to prove a hypothesis [19][20]. The sampling technique used is total sampling. This study took a random control group posttest. The sample of this study was 18 male Wistar rats aged 2-3 months with a bodyweight of 150-250 grams which were divided into the control group, theobromine group, and caffeine group. Thus, each group consisted of 6 male Wistar rats. The independent variables in this study were ergogenic substances, namely theobromine, and caffeine which were given to Wistar rats before maximum physical activity. Meanwhile, the dependent variable is the level of lactic acid which is intended to determine the level of muscle fatigue. The instrument for taking blood to measure lactic acid levels is accutrend plus. The test results are presented in the form of descriptive analysis, prerequisite tests. The data analysis test was carried out using one-way ANOVA using SPSS version 16. The study took place at the Biology Laboratory of the State University of Semarang from January 11 to January 25, 2016. The adaptation time for the three groups was given from the first day to the seventh day of the experiment. From the eighth day to the fourteenth day, the adaptation given to the theobromine and caffeine groups was in the form of maximum physical activity for one week. The purpose of this activity was to determine the results of lactic acid levels in Wistar male white rats as the control group, theobromine group, and the caffeine group.

\section{Results}

Descriptive data analysis found the weight of wistar rats in each group to be used as a sample. The results are presented in the following data:

Table 1. Description of Wistar Rat Weight

\begin{tabular}{|c|c|c|c|}
\hline \multicolumn{4}{|c|}{ Rat Weight (gram) } \\
\hline \multirow{4}{*}{$\mathrm{N}=6$} & Control & Theobromine & Caffeine \\
\cline { 2 - 4 } & 189 & 166 & 178 \\
& 214 & 196 & 159 \\
& 155 & 212 & 157 \\
& 232 & 195 & 226 \\
& 206 & 222 & 156 \\
& 217 & 164 & 173 \\
\hline Total & 1213 & 1155 & 1049 \\
\hline Average & 202.1 & 192.5 & 174.8 \\
\hline
\end{tabular}

Table 2. Analysis Results of Theobromine and Caffeine

\begin{tabular}{|c|c|c|c|}
\hline \multicolumn{4}{|c|}{ Posttest results of Rat Lactic Acid Levels (mmol) } \\
\hline & Control & Theobromine & Caffeine \\
\hline & 3.80 & 3.60 & 3.20 \\
& 4.30 & 5.30 & 3.40 \\
& 4.80 & 3.40 & 5.70 \\
& 5.10 & 4.30 & 3.90 \\
& 5.70 & 5.60 & 4.60 \\
& 7.40 & 7.20 & 4.10 \\
\hline Average & 5.2 & 4.9 & 4.2 \\
\hline
\end{tabular}

Referring to the data presented in Table 2, it is known that the average value of lactic acid levels in the control group after treatment was $5.2 \mathrm{mmol}$. On the other hand, the values in the theobromine and caffeine groups were 4.9 mmol and $4.2 \mathrm{mmol}$, respectively. Based on these average values, it was concluded that the caffeine group had lower levels of lactic acid than the theobromine and control groups. 
Table 3. Normality Test

\begin{tabular}{|c|c|c|c|}
\hline Variable & Statistic & Significance & Status \\
\hline Control Group & 0,472 & 0,979 & Normal \\
\hline $\begin{array}{c}\text { Theobromine } \\
\text { Group }\end{array}$ & 0,398 & 0,997 & Normal \\
\hline Caffeine Group & 0,462 & 0,983 & Normal \\
\hline
\end{tabular}

Based on table 3, the results of the normality test shows a significance value of 0.979 for the control group, 0.997 for the theobromine group, and 0.983 for the caffeine group. In other words, all variables are significantly greater than 0.05 so it can be concluded that all data are normally distributed.

Table 4. Homogeneity Test

\begin{tabular}{|c|c|c|}
\hline Variable & Statistic & Significance \\
\hline Control Group & 0,001 & 1.000 \\
\hline Theobromine Group & 0,001 & 1.000 \\
\hline Caffeine Group & 0,001 & 1.000 \\
\hline
\end{tabular}

Based on table 4, the homogeneity test shows a significance value of 1,000 for the control group, 1,000 for the theobromine group, and 1,000 for the caffeine group. The results obtained indicate that all variables are significantly greater than 0.05 so it can be concluded that all data are homogeneous.

Table 5. One Way Anova Hypothesis Testing

\begin{tabular}{|c|c|c|c|c|c|}
\hline \multicolumn{7}{|c|}{ Anova } \\
\hline & $\begin{array}{c}\text { Sum of } \\
\text { Square }\end{array}$ & df & $\begin{array}{c}\text { Mean } \\
\text { Square }\end{array}$ & F & Sig \\
\hline $\begin{array}{c}\text { Between } \\
\text { Groups }\end{array}$ & 3.421 & 2 & 1.711 & 1.145 & 0.34 \\
\hline $\begin{array}{c}\text { Within } \\
\text { Groups }\end{array}$ & 22.403 & 15 & 1.494 & & \\
\hline Total & 25.824 & 17 & & & \\
\hline
\end{tabular}

Table 5 above presents the results of the one-way ANOVA hypothesis test. Decision-making on the one-way ANOVA hypothesis test is if the significance value $>0.05$ indicates that the hypothesis is rejected. On the other hand, a significance value $<0.05$ means that the hypothesis is accepted. Thus, referring to the data presented, the significance value obtained in this study is $0.34>0.05$. In other words, the hypothesis is rejected. In conclusion, no significant difference was found in the control group, the theobromine group, and the caffeine group from the administration of the ergogenic theobromine and caffeine at the maximal activity. This is because based on the findings, the two substances did not significantly affect the level of muscle fatigue.

\section{Discussion}

This study was intended to determine the effect of giving theobromine and caffeine after maximum physical activity (swimming stress) for 7 days on reducing lactic acid levels in 18 male white rats of Wistar strain. There is a past study conducted by $\mathrm{Hu}$ [17] regarding the ergogenic effects of the intake of salbutamol, caffeine, and theobromine on non-asthmatic subjects. The study found that the completion time after administration of caffeine and administration of theobromine was lower than placebo $(p<0.05)$, so it was concluded that caffeine and theobromine were said to be able to improve performance in sports.

In the hypothesis test related to the comparison of lactic acid levels after maximal physical activity (swimming stress) for 7 days in the control group, the theobromine group and the caffeine group produced a significance value of 0.034 or greater than 0.05 . With these being obtained, it was concluded that there was no significant difference regarding the effect of theobromine and caffeine on fatigue due to maximal physical activity. This illustrates that the administration of theobromine and caffeine has not provided effective results on changes in lactic acid levels in each sample. The decrease in lactic acid levels cannot be known significantly because the data in this study did not use pretest data.

This finding is supported by the literature [9][12][17] which states that theobromine, pharmacologically, belongs to the category of xanthine derivatives. However, theobromine clinically has a low pharmacological effect and is relatively useless. On the other hand, a comparison between administration of theobromine and caffeine in the 500-meter interval sprint training showed that caffeine was successful in increasing performance in early running and theobromine at a later stage.

The results showed that the comparison of the average value of the sample in the group given theobromine at a dose of $0.9 \mathrm{mg}$ per 150-250 grams of body weight with maximum physical activity (swimming stress) for 7 days resulted in lower lactic acid levels, namely $4,9 \mathrm{mmol}$ compared to the control group with lactic acid levels of 5.2 mmol. Comparison of the average value in the sample given caffeine at a dose of $0.9 \mathrm{mg}$ per 150-250 grams of body weight and maximum physical activity (swimming stress) for 7 days resulted in lower lactic acid levels, namely $4.2 \mathrm{mmol}$ compared to the control group, $5.2 \mathrm{mmol}$. These results imply that the average lactic acid level in the caffeine-treated group was lower than the control group and the theobromine although no significant changes were found.

Referring to the results of the research and discussion that have been described, it is concluded that the effect of givin56g theobromine and caffeine on the maximum physical activity does not produce a significant effect on reducing lactic acid levels. Therefore, the authors suggest not consuming theobromine and caffeine to prevent muscle fatigue after maximal physical activity. The researcher's hope for further research is that the results of these findings can be used as a basic reference for relevant research. 


\section{Conclusions}

Summarizing the results and discussion, it was concluded that the administration of theobromine and caffeine had no significant effect on reducing lactic acid levels. It is thus recommended that theobromine and caffeine should not be consumed for the prevention of muscle fatigue.

\section{Acknowledgements}

The author would like to thank the Semarang State University who has provided support so that this article can be completed in a proper manner.

\section{REFERENCES}

[1] J. Yanci et al., "Sprint, agility, strength and endurance capacity in wheelchair basketball players," Biol. Sport, vol. 32, no. 1, pp. 71-78, 2015, doi: $10.5604 / 20831862.1127285$.

[2] Laddu, D. R., Lavie, C. J., Phillips, S. A., \& Arena, R. " Physical activity for immunity protection: Inoculating populations with healthy living medicine in preparation for the next pandemic," Progress in cardiovascular diseases, vol. 64, pp. 102, 2021

[3] Caldas de Almeida, J.M.; Mateus, P.; Frasquilho, D.; Parkkonen, J. "Eu Compass for Action on Mental Health and Wellbeing", European: Brussels, Belgium, 2016

[4] Parshukova, O. I., Varlamova, N. G., \& Bojko, E. R, "Nitric Oxide Production in Professional Skiers During Physical Activity at Maximum Load." Frontiers in Cardiovascular Medicine, vol. 7. pp. 320. 2020

[5] Bompa, T. O., \& Buzzichelli, C. "Periodization-: theory and methodology of training." Human kinetics. 2019

[6] Kenney, W. L., Wilmore, J. H., \& Costill, D. L. "Physiology of sport and exercise. Human kinetics.", 2015

[7] Fulton, T. J., Baranauskas, M. N., Paris, H. L., Koceja, D. M., Mickleborough, T. D., \& Chapman, R. F. "Respiratory Muscle Fatigue Alters Cycling Performance and Locomotor Muscle Fatigue". Medicine and Science in Sports and Exercise, vol. 52, no.11, pp.2380-2389, 2020

[8] Bogdanis, G. C. "Effects of physical activity and inactivity on muscle fatigue. Frontiers in physiology." vol.3, no.142, 2012

[9] Miladiyah, I., Trunogati, P., \& Lestariana, W.
"Perbandingan Efektivitas Teofilin (1, 3-Dimethylxanthine) dan Kafein (1, 3, 7-Trimethylxanthine) dalam Menunda Kelelahan Otot pada Tikus". Mutiara Medika: Jurnal Kedokteran dan Kesehatan, vol 17 no. 2 Juli, 2017

[10] Elshafei, M., \& Shihab, E. (2021). Towards Detecting Biceps Muscle Fatigue in Gym Activity Using Wearables. Sensors, 21(3), 759.

[11] Cairns, S. P. "Lactic acid and exercise performance." Sports medicine, vol.36 no.4, pp.279-291, 2006

[12] Kennedy, M. "Effects of theophylline and theobromine on exercise performance and implications for competition sport: A systematic review." Drug Testing and Analysis, vol.13, no.1, pp.36-43, 2021

[13] Muñoz, A., López-Samanes, Á., Pérez-López, A., Aguilar-Navarro, M., Moreno-Heredero, B., Rivilla-García, J., ... \& Del Coso, J. "Effects of caffeine ingestion on physical performance in elite women handball players: A randomized, controlled study." International journal of sports physiology and performance, vol.15, no.10, pp.1406-1413, 2020

[14] Jodra, P., Lago-Rodríguez, A., Sánchez-Oliver, A. J., López-Samanes, A., Pérez-López, A., Veiga-Herreros, P., ... \& Domínguez, R. "Effects of caffeine supplementation on physical performance and mood dimensions in elite and trained-recreational athletes." Journal of the International Society of Sports Nutrition, vol.17,no1, pp.1-11, 2020

[15] Grgic, J., Diaz-Lara, F. J., Del Coso, J., Duncan, M. J., Tallis, J., Pickering, C., ... \& Mikulic, P. "The effects of caffeine ingestion on measures of rowing performance: A systematic review and meta-analysis." Nutrients, vol.12, no.2, pp.434, 2020.

[16] Ferreira, T. T., da Silva, J. V. F., \& Bueno, N. B. "Effects of caffeine supplementation on muscle endurance, maximum strength, and perceived exertion in adults submitted to strength training: a systematic review and meta-analyses." Critical reviews in food science and nutrition, pp.1-14, 2020

[17] Hu, J." Ergogenic Effects of Intake of Salbutamol, Caffeine, and Theobromine on Non-Asthmatic Subjects. Liverpool John Moores University" United Kingdom, 2016.

[18] Ramírez-Vélez, R. "Actividad física y calidad de vida relacionada con la salud: revisión sistemática de la evidencia actual." Revista Andaluza de Medicina del Deporte, vol.3, no.3, pp.110-120,2010

[19] Iqbal, M. I., Mansyur, M., Sari, P., \& Suryandari, D. A. "The Effect of Exposure Process of Toluene To The Spermatogonia Cell a Rattus Strain Wistar." Journal Of The Indonesian Medical Association, vol.71, pp.11-17, 2021

[20] Emda, A.’Laboratorium sebagai sarana pembelajaran kimia dalam meningkatkan pengetahuan dan ketrampilan kerja ilmiah." Lantanida journal, vol.5, pp1, no.83-92, 2017. 